\title{
Vertical Transmission of Human Immunodeficiency Virus (HIV) Infection Reactivity of Maternal Sera with Glycoprotein 120 and 41 Peptides from HIV Type 1
}

\author{
Kenneth E. Ugen, ${ }^{\star \ddagger}$ James J. Goedert," Jean Boyer,* Yosef Refaeli," lan Frank, ${ }^{\ddagger}$ William V. Williams," Anne Willoughby," \\ Sheldon Landesman,' Hermann Mendez,' Arye Rubinstein,"** Thomas Kieber-Emmons,"* and David B. Weiner** \\ ${ }^{*}$ The Wistar Institute of Anatomy and Biology, Pennsylvania and ${ }^{\ddagger}$ Department of Medicine, University of Pennsylvania, Philadelphia, \\ Pennsylvania 19104; 'Laboratory of Viral Epidemiology, National Cancer Institute, Frederick, Maryland; "National Institute of Child \\ Health and Development Rockville, Maryland 20852; 'State University of New York Health Sciences Center at Brooklyn, \\ Brooklyn, New York 11203; and ${ }^{* *}$ Albert Einstein College of Medicine, Bronx, New York 10461
}

\begin{abstract}
The observation that $\sim 70 \%$ of HIV-infected pregnant women do not transmit infection vertically suggests that antibody therapy may be effective in the prevention of transmission of HIV infection from mother to child. Currently, there is an incomplete understanding of the processes involved in vertical transmission of HIV infection. The elucidation of the serological basis of maternal immunity as it relates to protection from vertical transmission is the goal of this study. We have screened 20 maternal sera from HIV+ individuals of known vertical transmission status for reactivity with 31 peptides spanning the entire envelope glycoprotein of HIV-1. Of interest was reactivity to regions outside of the V3 loop of gp120. The findings have been examined in relationship to transmission status, as well as to in vitro anti-HIV-1 biological activity. Our results indicate that lack of vertical transmission is correlated with high viral neutralization activity, but not with antisyncytial activity nor with binding to the V3 peptides examined in this study. Also, the transmission group bound to fewer gp41 peptides when compared with the nontransmission group, suggesting that immune responses to gp41 may be important in preventing transmission. These findings may provide insights into the design of passive immunotherapies. (J. Clin. Invest. 1992. 89:19231930.) Key words: synthetic peptides $\bullet$ protective humoral immunity • neutralization • syncytia • peptide-based immunity
\end{abstract}

\section{Introduction}

HIV is the etiologic agent of AIDS and related disorders $(1,2)$. The destruction of $\mathrm{CD4}^{+}$cells through direct infection by HIV is a hallmark of this disease (3). This depletion of the T helper subset ultimately results in profound immunosuppression. HIV-1 evades immune surveillance by multiple mechanisms, including the inhibition of immune responsiveness through deletion of $\mathrm{CD}^{+}$cells and extensive variation of envelope proteins, gp120 and gp41 (4).

Progression to symptomatic disease states in HIV-infected individuals is correlated with lower humoral and in vitro $\mathrm{T}$ cell immune responses. Antisyncytial and group-specific neutraliza-

Address correspondence and reprint requests to Dr. David B. Weiner, The Wistar Institute, 3601 Spruce St., Philadelphia, PA 19104.

Received for publication 9 August 1991 and in revised form 5 December 1991

\section{J. Clin. Invest.}

(c) The American Society for Clinical Investigation, Inc.

0021-9738/92/06/1923/08 \$2.00

Volume 89, June 1992, 1923-1930 tion activity are observed more frequently in the asymptomatic patient population than in patients with AIDS. Several peptides corresponding to defined regions of the HIV envelope, including the V3 loop region of gp120, are able to induce protective immune responses in experimental animals; this result suggests that a complete understanding of the complex nature of the anti-HIV envelope responses will enable development of immunologically relevant strategies which will benefit HIV-infected individuals.

Pediatric AIDS is an important medical problem (5). Current estimates indicate that women now represent $12 \%$ of AIDS cases in the US and that $80 \%$ of these HIV-infected women are of child-bearing age. Of these HIV-infected women, $\sim 6,000$ bear children each year, and it is estimated that about $1,200-2,100$ of these infants will be infected by HIV.

The timing and mechanism of viral infection of the fetus or neonate is being intensely investigated but is still incompletely understood. Studies support vertical transmission of HIV to the fetus in utero, and to the neonate at the time of delivery or postpartum. In fact, HIV has been cultured, or HIV DNA detected in abortuses of less than $15 \mathrm{wk}$ of gestational age $(6,7)$. In utero, transmission of HIV is also supported by the fact that children can become infected despite delivery by Cesarean section (8). However, most infected newborns appear clinically and immunologically normal at birth. Some children may be infected after exposure to maternal blood at the time of delivery. In addition, the exchange of blood before birth or at birth between the mother and infant has been documented, and maternal lymphocytes can be found in the circulation of the child at birth. Also, postpartum infection has been documented in children exposed to breast milk (9).

It is unknown if free virus can cross the placenta, but infected maternal blood cells can be found postpartum in the circulation of some infants and these cells can support HIV infection in vitro. In addition, HIV-1 infection has been observed by immunochemical and molecular methods in villous trophoblastic derivatives, villous mesenchymal cells, and embryonic blood precursors of an 8-wk gestational fetus (10).

Despite the evidence that HIV infection of children can occur in utero, $65-80 \%$ of all infants seem to escape infection (11). Little is known about the immune responses that might affect perinatal transmission of HIV. There are data suggestive of a protective role for humoral immunity in vertical transmission of HIV infection. Four studies have suggested a correlation between the presence of certain maternal antibodies and a reduced incidence of infection in the infant (12-15). In each study, the antibody measured was directed against the gp120 envelope protein. High titer anti-gp 120 antibodies against conserved portions of the V3 hypervariable loop of gp120, and high affinity/avidity antibodies against the principal neutraliz- 
ing domain (PND) of the V3 hypervariable loop have been identified as potential correlates of protection. Maternal antibody may protect the fetus by reducing the quantity of infectious virus in the maternal circulation or by passive transfer of protective antibody to the fetus during the last 3-4 mo of pregnancy. One report suggested an increased incidence of HIV infection in premature infants who may have lower levels of passively acquired maternal antibody (16). So far, no information is available to assess the ability of antibodies from an individual mother to neutralize or react with the virus variant transmitted to her own infant. Additionally, there has been no detailed analysis of the contribution of the humoral immune response to regions outside the $\mathrm{V} 3$ region and maternal HIV transmission.

The goal of the present study is to identify humoral immune responses which may be protective against the vertical transmission of HIV. The identification of specific protective immune responses would enhance the promise of immunebased therapy to prevent prenatal and perinatal transmission of HIV.

\section{Methods}

Patient samples. The maternal sera and plasma samples were obtained through a collaborative investigation with the Mothers/Infants Cohort Study (14). Briefly, the Mothers/Infants Cohort Study is a prospective investigation, and the sera samples in this study were from women attending obstetric clinics in New York City. All the women were drug abusers and/or Haitian. They were all established to be HIV seropositive by ELISA and Western blot analysis during the first trimester (17, 18). Sample number 13 was from a mother in the process of seroconverting late in the third trimester, and this particular sample, although weakly reactive in enzyme-linked immunosorbent assay against viral lysate and several peptides, was not unequivocally positive by standard whole virus Western blot.

In addition, information on the HIV infected status of the offspring of these women was also available. Seropositive mothers whose infants are found to meet the Centers for Disease Control (CDC) definition of perinatal HIV-1 infection are classified as transmitting mothers, whereas seropositive mothers of children with no sign of infection and who have lost maternal antibody are classified as nontransmitting mothers (19). In this study, 13/20 of the mothers (65\%) are classified as transmitters, whereas $7 / 20$ of the mothers $(35 \%)$ are classified as nontransmitters. Of the seven infected children, two had asymptomatic infection (CDC Classification: P-1) while five had symptomatic infection (CDC Classification: P-2). All of the maternal serum samples tested in this study were drawn during the last trimester of pregnancy. These patient samples were heat inactivated for $60 \mathrm{~min}$ at $56^{\circ} \mathrm{C}$ before use in peptide binding or biological characterization assays.

Cell lines. The $\mathrm{H} 9$ cell line (a cutaneous $\mathrm{T}$ lymphoma line) infected by HIV-IIIB was used in the neutralization assay. The H9 cell line infected by HIV-MN was used in the antisyncytial assays. SupT1 and Hut 78 cells were used as the target cell lines for the antisyncytial and neutralization assays respectively. All cell lines were obtained from the National Institutes of Health AIDS Repository (Bethesda, MD).

gp41 and gp120 peptides. Synthetic peptides were developed by methods previously described (20). The gp 120 and gp41 peptides used in these assays are listed in Table I. They were synthesized based on the sequence of the IIIB isolate of HIV-1. Each of the peptides was at least $80 \%$ pure, making them suitable for ELISA/RIA assays. The following peptides used in this study were generous gifts of Dr. Jay Berzofsky of the National Institute of Health: 35, 36, 40, 41, 93, 94, 95, 96, 97, 106, $107,117,120,121,123,128,129$, and 132 .

RIA and ELISA binding assays. RIA and ELISA were performed by standard methodologies $(21,22)$ Peptides were dissolved in $0.05 \mathrm{M}$ carbonate-bicarbonate buffer ( $\mathrm{pH} 9.6$ ) at a concentration of $10 \mu \mathrm{g} / \mathrm{ml}$. $50 \mu \mathrm{l}(500 \mathrm{ng})$ of the peptides were immobilized in 96-well polyvinyl- chloride plates (Dynatech Laboratories, Inc., Alexandria, VA) overnight at $4^{\circ} \mathrm{C}$. Plates were washed and nonspecific sites were blocked with PBS containing $1 \%$ BSA (blocking buffer) overnight at $4^{\circ} \mathrm{C}$. Dilutions of HIV-positive maternal sera were made in blocking buffer at dilutions of 1:50 and 1:500, and incubated in peptide coated plates overnight at $4^{\circ} \mathrm{C}$. Plates were washed with PBS and incubated with $75,000 \mathrm{cpm}$ of ${ }^{125} \mathrm{I}$-labeled goat anti-human IgG. The antibody was iodinated by a chloramine T method previously described (23). Plates were washed, dried, and counted in a gamma counter to measure specific binding. Normal human serum (i.e., HIV seronegative) was used as a control. Alternatively, ELISA assays were performed in polystyrene plates (Dynatech Laboratories, Inc.) in which $0.05 \%$ Tween 20 (Sigma Chemical Co., St. Louis, MO) was included in the washing, blocking, and dilution buffers. The secondary antibody used was goat anti-mouse Ig conjugated to horseradish peroxidase (HRP; Sigma Chemical Co.). The substrate used for color development was 3,3',5,5 tetramethyl-benzidine dihydrochloride (TMB; Sigma Chemical Co). Absorbance of samples was measured in a plate reader (MR5000; Dynatech Laboratories, Inc.) and expressed as OD450 $\mathrm{nm}$.

The results of the binding assays are represented in Tables II and IV.

Antisyncytial assay. To analyze the effect of the maternal serum samples on HIV-1 fusion, SupT1 cells were used as target cells. Dilutions of the different maternal serum samples were made in 96-well plates in RPMI 1640 media containing $10 \%$ FCS at final dilutions of $1: 4,1: 8,1: 16,1: 32,1: 64,1: 128,1: 256$, or 1:512. HIV-1 infected cells (MN isolate) were then plated in the wells at a density of $\sim 10^{4}$ cells/ well. SupT 1 target cells were then added at $5 \times 10^{5} /$ well, and the number of syncytia are determined after $3 \mathrm{~d}$ of incubation. Inhibition of syncytium formation by a serum sample was considered significant if the dilution which yielded a $50 \%$ reduction in the number of syncytia when compared with control was greater than 1:32. The average number of syncytia in the control (NHS) wells at the above dilutions were $45.5,48.5,44,48,48.5,41.5,42$, and 45.5 respectively.

Neutralization assay. $20 \mu \mathrm{l}$ of maternal sera samples was placed in 96 round-bottom-well plates at final dilutions of 1:10,1:90, and 1:810 in RMPI. The HIV-IIIB viral isolate was diluted in RPMI to a TCID $_{50}$ of $100 \mathrm{U} / \mathrm{ml} .20 \mu \mathrm{l}$ of the virus solution was placed in each well, and the plate was incubated for 1 hour at $4^{\circ} \mathrm{C}$. Hut-78 cells were incubated with $2 \mu \mathrm{g} / \mathrm{ml}$ of polybrene for $1 \mathrm{~h}$ at $37^{\circ} \mathrm{C}$ in a $\mathrm{CO}_{2}$ incubator. The HUT-78 cells were washed and resuspended in fresh RPMI to a final concentration of $4 \times 10^{6}$ cells $/ \mathrm{ml} .10 \mu \mathrm{l}$ of the cell suspension was added to each well, and the plate was incubated for $1 \mathrm{~h}$ in a $37^{\circ} \mathrm{C}, \mathrm{CO}_{2}$ incubator. 15 $\mu \mathrm{l}$ of the serum/cell per virus solution was aliquoted to a new plate containing $200 \mu \mathrm{l}$ of fresh RPMI and incubated for $6 \mathrm{~d}$. After $6 \mathrm{~d}, 100 \mu \mathrm{l}$ was used to analyze for p24 antigen. The p24 capture ELISA assay kit, designed by the Coulter Electronics Inc. (Hialeah, FL) was used to perform the measurements.

Further, sera samples at the same dilutions as described above were tested for residual p24 core protein or antibody to insure the results were due only to viral infection. All samples failed to demonstrate residual p24 antigen or anti-p24 antibody at the above dilutions when tested in the p24 ELISA assay kit.

Neutralizing activity by a serum sample was considered significant if the dilution which yielded a $50 \%$ reduction in OD450 $\mathrm{nm}$ (a measure of p24 antigen levels) when compared with control was greater than 1:10 (i.e., in this assay dilutions of $1: 90$ or $1: 810$ ).

Statistical analysis. Comparisons of number of peptides which bound maternal serum samples were made between the transmission group and the nontransmission group. The data was analyzed using the unpaired Student's $t$ test. For the determination of differences in the binding of specific peptides between transmission and nontransmission groups, the Spearman's rank-order correlation test was performed.

\section{Results}

Binding of maternal sera to peptides from gp120 and gp 41 14 peptides, spanning $46 \%$ (a total of 239 aa) of the gp120 external membrane glycoprotein, and 17 peptides spanning 
$66 \%$ (a total of $236 \mathrm{aa}$ ) of the gp41 transmembrane glycoprotein were used in binding assays of the maternal serum samples. The approximate location of these peptides on a linear map of gp120 and 41 is shown in Fig. 1. Binding was examined by RIA or ELISA. A list of the gp120 and gp41 peptides tested, their location in the envelope glycoprotein, and sequences are given in Table I.

Binding to peptides from the amino terminus of gp120. Several maternal serum samples had reactivity to 1 or more of 3 peptides spanning aa 51 through 85 of the amino terminus of gp1 20 (peptides 93, 94, and 95, Table II). No binding of maternal sera to 4 peptides from the amino terminus (peptides 59, 60,96 , and 97) was observed. Peptides 96 and 97 are from a region near to the putative sites for the binding of $\mathrm{gp} 120$ to gp41, and deletion of the amino acid residues within this region of gp1 20 inhibits viral receptor binding of the CD4 molecule (24). Of the six maternal sera binding to peptide 93 , one (17\%) was from the vertical transmission group and five (83\%) were from the nontransmission group. In addition, three $(50 \%)$ and six $(100 \%)$ of the six samples which bound possessed neutralization and antisyncytial activity, respectively. Of the two maternal sera binding to peptide 94 , neither were from the vertical transmission group. Of the three maternal sera binding to peptide 95 , one was from the vertical transmission group.

Binding to peptides from the V3 loop of $\mathrm{gp120}$. There was significant binding of a number of the maternal serum samples to peptides from the V3 loop of gp120. The peptides 106, 107, 1029-33, and p18p span amino acids 296-322, and 30, 95, 50, and $35 \%$ of the maternal serum samples bound to these peptides, respectively. Other investigators have determined a correlation between binding to particular regions of the V3 loop and protection from transmission of infection (13-15). Our results do not support such a relationship (Table III).

Binding to peptides from the CD4 binding site. Peptide B138 spans aa 421 through 438 . Seven of the maternal samples reacted to peptide $B 138$. This is an interesting observation since in other reports this region has appeared to be immunosilent in HIV-infected patients. Of those samples that bound, two were from the vertical transmission group.

Binding to peptides from the carboxy terminus. $16(80 \%)$ of
Table I. gp120 and gp41 Peptides Screened in Assay

\begin{tabular}{|c|c|c|c|}
\hline $\begin{array}{c}\text { Peptide } \\
\text { name }\end{array}$ & $\begin{array}{c}\text { First } \\
\text { amino } \\
\text { acid }\end{array}$ & $\begin{array}{l}\text { Last } \\
\text { amino } \\
\text { acid }\end{array}$ & Sequence \\
\hline \multicolumn{4}{|r|}{ gp120 Peptides } \\
\hline 60 & 031 & 052 & ATEKLWVTVYYGVPVWLEATTTL \\
\hline 93 & 051 & 065 & TLFCASDAKAYDTEV \\
\hline 94 & 061 & 075 & YDTEVHNVWATHACV \\
\hline 95 & 071 & 085 & THACVPTDPNPQEVV \\
\hline 96 & 081 & 095 & PQEVVLVNVTGENFNM \\
\hline 97 & 127 & 141 & VSLKCTDLKNDTNTN \\
\hline 59 & 145 & 165 & SSGRMIMEKGEIKNCSFNIST \\
\hline 106 & 296 & 310 & CTRPNNNTRKSIRIQ \\
\hline 107 & 303 & 317 & TRKSIRIQRGPGRAF \\
\hline $1029 / 33$ & 304 & 314 & RKSIGIQRGPGR \\
\hline p18p & 308 & 322 & RIQRGPGRAFVTIGK \\
\hline B138 & 421 & 438 & KQFINMWQEVGKAMYAPP \\
\hline 466 & 468 & 483 & CFRPGGGDMRDNWREL \\
\hline 497 & 499 & 511 & CTKAKRRVVQREKA \\
\hline \multicolumn{4}{|r|}{ gp41 Peptides } \\
\hline 117 & 515 & 529 & IGALFLGFGAAGST \\
\hline 560 & 548 & 577 & CIVQQQNNLLRAIEAQQHLLQLTVWGIKQL \\
\hline 35 & 553 & 574 & QNNLLRAIEAQQHLLQLTVWGI \\
\hline 120 & 572 & 585 & WGIKQLQARILAVER \\
\hline 121 & 581 & 595 & LAVERYLKDQQLLGI \\
\hline 123 & 601 & 615 & KLICTTQVPWNASWS \\
\hline 36 & 612 & 626 & ASWSNKSLEQIWNNM \\
\hline 40 & 632 & 646 & DREINNYTSLIHSLI \\
\hline 41 & 637 & 651 & NYTSLIHSLIEESQNQ \\
\hline 649 & 649 & 662 & QNQQEKNEQELLEL \\
\hline 53 & 662 & 682 & ELDKWASLWNWFNITNWLWY \\
\hline 55 & 696 & 716 & LRIVFAVLSVVNRVRQGYSP \\
\hline 128 & 711 & 725 & GYSPLSFQTHPIPR \\
\hline 129 & 736 & 750 & EGGERDRDRSIRLVN \\
\hline 132 & 766 & 780 & FSYHRLRDLLLIVTR \\
\hline 57 & 778 & 797 & VTRIVELLGRRGWEALKYWW \\
\hline $1103 / 55$ & 817 & 841 & NATAIAVAEGTDRVIEVVQGAYRAI \\
\hline
\end{tabular}

the maternal sera samples bound to peptide 497 which spans aa $499-511$ of the carboxy terminus of $g p 120.77$ and $71 \%$ of the samples from the transmission and nontransmission group, respectively, bound to this peptide. This region is immunoactive,
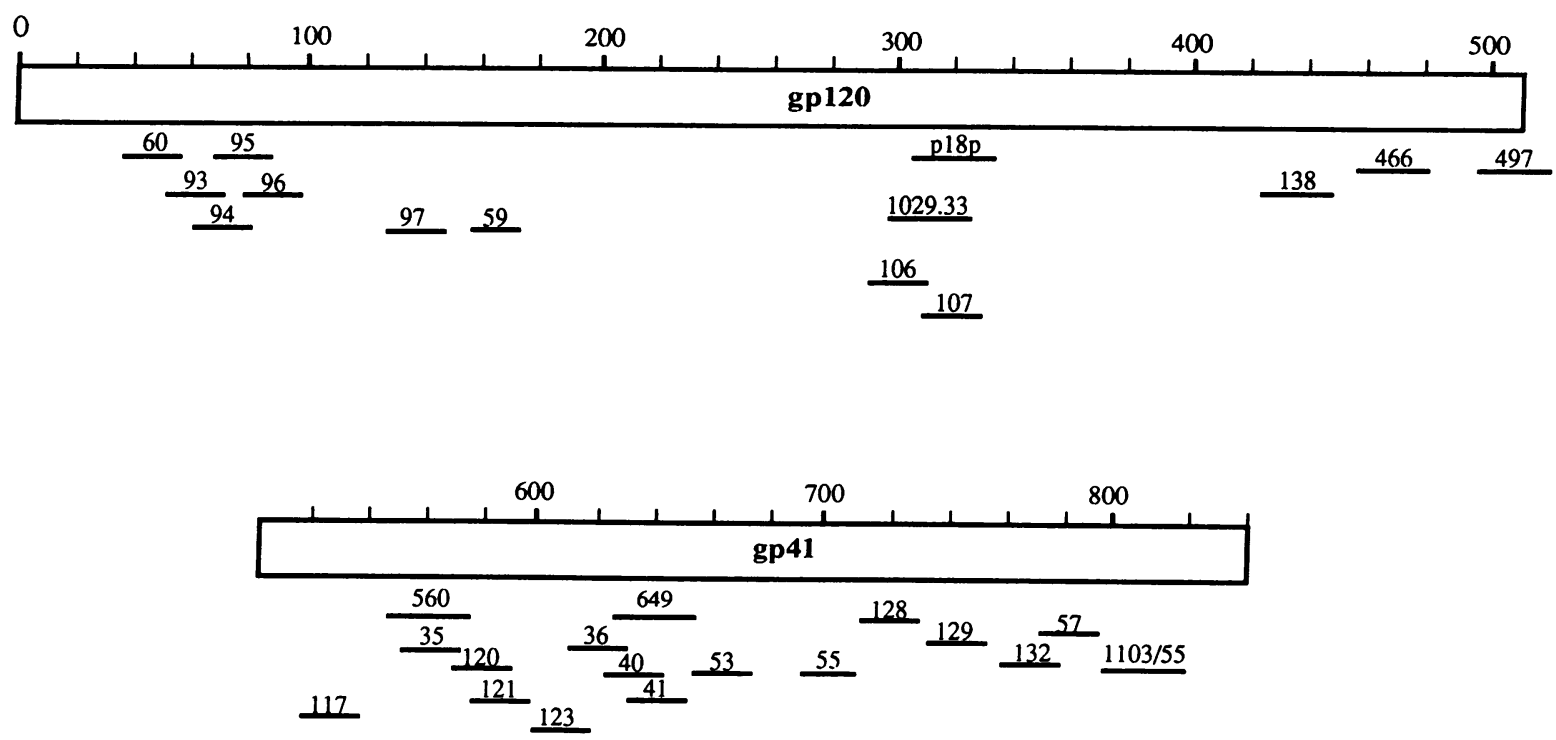

Figure 1. A linear map of $\mathrm{gp} 120$ and gp41 is shown with the amino acid number above the map. The approximate location and designation of the peptides used in this study are shown on this map. 
Table II. Screening of Maternal HIV ${ }^{+}$Sera Against Peptides from gp120

\begin{tabular}{|c|c|c|c|c|c|c|c|c|c|c|c|c|c|c|}
\hline \multirow{2}{*}{$\begin{array}{c}\text { Sera } \\
\text { no. }\end{array}$} & \multicolumn{14}{|c|}{ Peptides } \\
\hline & 60 & 93 & 94 & 95 & 96 & 97 & 59 & 106 & 107 & $1029-33$ & p18p & B138 & 466 & 497 \\
\hline \multicolumn{15}{|c|}{ Nontransmission group } \\
\hline 1 & - & ++ & ++ & + & - & - & - & - & ++ & + & - & + & - & - \\
\hline 2 & - & - & - & - & - & - & - & - & ++ & ++ & - & + & - & ++ \\
\hline 3 & - & - & ++ & - & - & - & - & - & ++ & + & - & - & - & ++ \\
\hline 6 & - & + & - & - & - & - & - & - & ++ & - & - & + & + & + \\
\hline 7 & - & ++ & - & - & - & - & - & - & + & - & - & ++ & - & - \\
\hline 8 & - & + & - & - & - & - & - & - & ++ & - & - & ++ & - & ++ \\
\hline 9 & - & - & - & - & - & - & - & - & ++ & - & - & - & ++ & ++ \\
\hline 11 & - & - & - & + & - & - & - & - & ++ & + & - & - & - & ++ \\
\hline 12 & - & - & - & - & - & - & - & - & ++ & + & ++ & - & - & - \\
\hline 16 & - & + & - & - & - & - & - & + & ++ & - & + & - & - & ++ \\
\hline 18 & - & - & - & - & - & - & - & - & ++ & - & - & - & + & + \\
\hline 20 & - & - & - & - & - & - & - & + & ++ & ++ & + & - & - & + \\
\hline
\end{tabular}

Transmission group

\begin{tabular}{|c|c|c|c|c|c|c|c|c|c|c|c|c|c|}
\hline- & ++ & - & - & - & - & - & - & ++ & - & - & + & - & ++ \\
\hline- & - & - & - & - & - & - & - & ++ & + & - & + & - & + \\
\hline- & - & - & - & - & - & - & - & + & - & - & - & - & + \\
\hline- & - & - & - & - & - & - & ++ & ++ & + & ++ & - & - & - \\
\hline- & - & - & ++ & - & - & - & ++ & ++ & - & ++ & - & - & - \\
\hline- & - & - & - & - & - & - & ++ & - & + & ++ & - & - & ++ \\
\hline- & - & - & - & - & - & - & - & ++ & - & - & - & - & + \\
\hline
\end{tabular}

The following key is used for the designation of binding of the maternal sera samples to the peptides:

$$
\begin{aligned}
& -=\frac{\text { specific OD450 } \mathrm{nm} \text { or cpm of sera sample binding to peptide }}{\text { specific OD450 } \mathrm{nm} \text { or cpm of NHS sample binding to peptide }}<2 \\
& +=\frac{\text { specific OD450 } \mathrm{nm} \text { or cpm of sera sample binding to peptide }}{\text { specific OD450 } \mathrm{nm} \text { or cpm of NHS sample binding to peptide }} \text { is between } 2 \text { and } 3 \\
& ++=\frac{\text { specific OD450 } \mathrm{nm} \text { or cpm of sera sample binding to peptide }}{\text { specific OD450 } \mathrm{nm} \text { or cpm of NHS sample binding to peptide }}>3
\end{aligned}
$$

Specific binding is defined as:

(OD450 $\mathrm{nm}$ or cpm of sera to wells with peptide) - (OD450 $\mathrm{nm}$ or $\mathrm{cpm}$ of sera to wells without peptide).

but antisera generated to this peptide do not demonstrate neutralizing activity (unpublished observation). In addition, 15\% of the maternal serum samples demonstrated reactivity to peptide 466 , which spans aa 468 through 483 of gp120. Zero and

Table III. Lack of Correlation Between Vertical Transmission and Binding of Maternal Sera to V3 Loop Peptides

\begin{tabular}{lcccc}
\hline & \multicolumn{4}{c}{ Peptides } \\
\cline { 2 - 5 } Transmission status & 106 & 107 & $1029-33$ & p18p \\
\hline $\begin{array}{c}\text { Transmitter } \\
\quad \begin{array}{l}n=7 \\
\text { Nontransmitter } \\
n=13\end{array}\end{array}$ & 42.9 & 85.7 & 42.9 & 42.8 \\
& 23.0 & 100 & 53.8 & 30.7
\end{tabular}

Values are the percentages of sera samples from each group demonstrating binding to peptide. three of the maternal samples from the transmission and nontransmission groups, respectively, bound to this peptide. Of the three maternal samples that bound to peptide 466 , all of them demonstrated neutralizing and antisyncytial activity. Antisera generated in animals against this peptide have been demonstrated to exhibit neutralizing activity (25). In particular, one maternal serum (No. 9) demonstrated very strong binding to peptide 466 and also demonstrated high neutralizing and antisyncytial activity. It is not clear whether this activity is due to binding to peptide 466 . Table II summarizes binding data of the maternal sera samples to the peptides from gp 120 .

\section{Binding of maternal sera to peptides from gp41}

In examining the binding of the maternal sera to peptides from gp41, it is evident that major reactivities to three peptides occur. Peptides 121(aa 581-595), 649(aa 649-663), and 110355(aa 817-841), demonstrated binding of 35,70 , and $45 \%$ of the maternal sera samples, respectively. Spearman rank-order correlation coefficient analysis indicates that there is a signifi- 
Table IV. Screening of Maternal HIV ${ }^{+}$Sera against Peptides From gp4I

\begin{tabular}{|c|c|c|c|c|c|c|c|c|c|c|c|c|c|c|c|c|c|}
\hline \multirow{2}{*}{$\begin{array}{c}\text { Sera } \\
\text { no. }\end{array}$} & \multicolumn{17}{|c|}{ Peptides } \\
\hline & 117 & 560 & 35 & 120 & 121 & 123 & 36 & 40 & 41 & 649 & 53 & 55 & 128 & 129 & 132 & 57 & 1105-55 \\
\hline \multicolumn{18}{|c|}{ Nontransmission group } \\
\hline 1 & - & + & - & - & ++ & + & - & - & - & ++ & - & - & - & + & + & - & - \\
\hline 2 & - & - & - & - & - & - & - & - & - & + & - & - & - & - & - & - & ++ \\
\hline 3 & - & - & + & - & - & - & - & - & - & + & - & - & - & - & - & - & - \\
\hline 6 & - & - & - & - & ++ & - & - & - & - & ++ & - & - & - & - & - & - & ++ \\
\hline 7 & - & - & + & - & - & - & - & - & - & ++ & - & - & - & - & - & - & ++ \\
\hline 8 & - & - & - & - & - & - & - & - & - & ++ & ++ & - & - & - & - & ++ & ++ \\
\hline 9 & - & - & - & - & - & - & - & - & - & - & - & - & - & - & + & - & - \\
\hline 11 & - & - & - & - & - & - & - & - & - & ++ & - & - & - & - & - & - & - \\
\hline 12 & - & - & - & - & - & - & - & - & - & ++ & - & - & - & - & - & - & ++ \\
\hline 16 & - & - & - & - & ++ & - & - & - & - & - & - & - & - & - & - & - & - \\
\hline 17 & - & - & - & - & ++ & - & - & - & - & + & + & - & - & - & - & - & ++ \\
\hline 18 & - & - & - & - & ++ & - & - & - & - & + & - & - & - & - & - & - & ++ \\
\hline 20 & - & - & - & - & - & - & - & - & - & - & - & - & - & - & - & + & - \\
\hline \multicolumn{18}{|c|}{ Transmission group } \\
\hline 4 & - & - & - & - & - & - & - & - & - & + & - & - & - & - & - & - & ++ \\
\hline 5 & - & - & - & - & - & - & - & - & - & - & - & - & - & - & - & - & - \\
\hline 10 & - & - & - & - & - & - & - & - & - & - & - & - & - & - & - & - & - \\
\hline 13 & - & - & - & - & - & - & - & - & - & - & - & - & - & - & - & - &. \\
\hline 14 & - & - & - & - & ++ & - & - & - & - & + & - & - & - & - & - & - & ++ \\
\hline 15 & - & - & - & - & ++ & - & - & - & - & + & - & - & - & - & - & - & - \\
\hline 19 & - & - & - & - & - & - & - & - & - & - & - & - & - & - & - & - & - \\
\hline
\end{tabular}

See key on Table II for legend.

cant difference in binding of samples from the transmission group to peptide 649 , compared with the nontransmission group, suggesting that binding to this peptide is correlated with nontransmission status. Table IV summarizes binding data of the maternal sera samples to peptides from gp41.

Quantitative analysis of binding to the peptides is shown in Table V. Of the 13 maternal sera samples from the nontransmission group $100 \%$ demonstrated binding to at least one peptide of both the gp41 and gp120 peptide groups. In contrast, of the seven maternal samples from the transmission group, all bound to at least one of the gp 120 peptides, but only three $(43 \%)$ bound to at least one of the gp41 peptides.

\section{Anti-gp120 and gp41 responses}

In terms of the average number of peptides to which the transmission and nontransmission groups bound, the following relationships can be determined: the transmission group bound to an average of $1.1 \pm 0.45 \mathrm{gp} 41$ peptides and $3.4 \pm 0.37 \mathrm{gp} 120$ peptides for a total of $4.5 \pm 0.75$. Conversely, the nontransmission group bound to an average of $2.4 \pm 0.40 \mathrm{gp} 41$ and $4.2 \pm 0.35$ gp 120 peptides for a total of $6.6 \pm 0.57$. Statistically, there was a significantly higher average number of gp41 and combined (gp41 + gp 120) peptides to which the sera from the nontransmission group bound, compared with the transmission group

Table V. Differences in Binding Patterns of Maternal HIV Positive Sera from the Vertical Transmission and Nontransmission Groups to Peptides from gp120 and gp41

\begin{tabular}{|c|c|c|c|c|c|}
\hline $\begin{array}{l}\text { Transmission } \\
\text { status }\end{array}$ & $\begin{array}{c}\% \text { of Sera } \\
\text { binding to } \\
\text { gp41 peptides }\end{array}$ & $\begin{array}{c}\% \text { of Sera } \\
\text { binding to } \\
\text { gp120 peptides }\end{array}$ & $\begin{array}{c}\text { Average no. of } \\
\text { gp4l peptides } \\
\text { to which } \\
\text { sera samples bind } \\
\text { (\%) }\end{array}$ & $\begin{array}{c}\text { Average no. of } \\
\text { gp120 peptides } \\
\text { to which } \\
\text { sera samples bind } \\
\text { (\%) }\end{array}$ & $\begin{array}{c}\text { Average no. of } \\
\text { gp } 120+\mathrm{gp} 41 \\
\text { peptides to } \\
\text { which sera binds }\end{array}$ \\
\hline \multicolumn{6}{|l|}{ Transmitter } \\
\hline$n=7$ & 43 & 100 & $1.1 \pm 0.45(24)$ & $3.4 \pm 0.37(76)$ & $4.5 \pm 0.75$ \\
\hline \multicolumn{6}{|l|}{ Nontransmitter } \\
\hline$n=13$ & 100 & 100 & $2.4 \pm 0.40 *(36)$ & $4.2 \pm 0.35(64)$ & $6.6 \pm 0.57^{*}$ \\
\hline
\end{tabular}

${ }^{*} P<0.05$ by the unpaired Student's $t$ test compared with the transmission group. Average no. is expressed as the mean \pm standard error of the mean. 
Table VI. Summary of Antisyncytial, Neutralization and Peptide Binding Reactivities of Maternal Sera Samples

\begin{tabular}{|c|c|c|c|c|}
\hline \multirow[t]{2}{*}{$\begin{array}{l}\text { Maternal sera } \\
\text { samples }\end{array}$} & \multirow{2}{*}{$\begin{array}{c}\begin{array}{c}\text { Antisyncytial } \\
\text { activity }\end{array} \\
\\
\text { Dilution } \\
\text { resulting in } \\
\geq 50 \% \\
\text { inhibition* }\end{array}$} & \multirow{2}{*}{$\begin{array}{c}\begin{array}{c}\text { Neutralization } \\
\text { activity }\end{array} \\
\\
\text { Dilution } \\
\text { resulting in } \\
\geq 50 \% \\
\text { inhibition }\end{array}$} & \multicolumn{2}{|c|}{ Peptide binding reactivity } \\
\hline & & & $\begin{array}{c}\text { Number of } \\
\text { gp41 } \\
\text { peptides } \\
\text { bound } \\
(+ \text { or }++)\end{array}$ & $\begin{array}{c}\text { Number of } \\
\text { gp120 } \\
\text { peptides } \\
\text { bound } \\
(+ \text { or }++)\end{array}$ \\
\hline
\end{tabular}

Nontransmission group

$\begin{array}{rlcll}1 & 1: 64 & - & 6 & 6 \\ 2 & 1: 32 & - & 2 & 4 \\ 3 & 1: 256 & 1: 90 & 2 & 4 \\ 6 & 1: 512 & 1: 90 & 3 & 5 \\ 7 & 1: 64 & 1: 810 & 3 & 3 \\ 8 & 1: 128 & - & 4 & 4 \\ 9 & 1: 256 & 1: 810 & 1 & 3 \\ 11 & 1: 256 & 1: 810 & 1 & 4 \\ 12 & 1: 512 & 1: 90 & 2 & 3 \\ 16 & 1: 512 & 1: 810 & 1 & 5 \\ 17 & 1: 256 & 1: 810 & 4 & 5 \\ 18 & 1: 64 & 1: 810 & 3 & 3 \\ 20 & 1: 256 & 1: 10 & 1 & 5\end{array}$

Transmission group

$\begin{array}{rcccc}4 & 1: 256 & 1: 10 & 2 & 4 \\ 5 & 1: 128 & - & 0 & 4 \\ 10 & 1: 256 & - & 0 & 2 \\ 13 & 1: 128 & 1: 10 & 0 & 4 \\ 14 & 1: 128 & 1: 10 & 3 & 4 \\ 15 & 1: 256 & 1: 810 & 2 & 4 \\ 19 & 1: 256 & 1: 10 & 0 & 2\end{array}$

* Values are the lowest dilution of maternal sera which results in at least $50 \%$ decrease in the number of syncytia formed per well when compared with normal human serum. ${ }^{\ddagger}$ Values are the lowest dilution of maternal sera which results in at least $50 \%$ decrease in absorbance OD450 $\mathrm{nm}$ (a measure of p24 antigen levels), when compared with normal human sera. - Indicates negative (i.e., a dilution of $<1: 10)$

$(P<0.05)$ (Table V). These data suggest that immune responses directed against gp41 may be involved in protection of the fetus from infection by HIV-1.

\section{Neutralization and antisyncytial activity}

Table VI summarizes data on antisyncytial and neutralization activity for each of the maternal serum samples. In addition, these data are shown in relationship to gp41 and gp120 binding reactivities for each of the sera samples.

As indicated, there is no correlation between transmission and nontransmission status in antisyncytial activity. By the definition established for antisyncytial activity (titer $>1: 32$ ), all maternal sera samples except no. 2 possessed significant antisyncytial activity.

According to the definition established for neutralizing ability (titer $>1: 10) 9 / 13(69.2 \%)$ of nontransmitting mothers and $1 / 7(14.3 \%)$ of transmitting mothers possessed neutralizing activity, respectively. These data indicate a relationship between high neutralization titers of maternal sera and nontransmission status.

\section{Discussion}

The observation that $\sim 70 \%$ of HIV positive mothers do not transmit infection to their offspring provides a useful model for examination of the putative mechanisms of protective humoral immune responses. Although there is some evidence that an infant can protect itself from infection by an active cell-mediated immune response, the objective of the studies presented in this report is to determine whether there is a maternal serological correlation with the transmission of HIV from mother to child. We have examined this question by measuring specific binding of maternal sera samples to a library of peptides from gp160 (gp120 + gp41).

The humoral immune response is an important component of protective immunity against a number of infectious agents. In many cases, neutralizing antibodies are generated against the infectious agents. These are antibodies that, regardless of the mechanism employed, can inhibit the infection of healthy cells. Most of the targets for neutralizing antibodies against HIV-1 reside on the viral envelope gene products (gp120 and gp41). Several HIV-1 neutralization epitopes have been identified on the external membrane glycoprotein (gp120). These include: (a) a region near the amino terminus which has been shown to be important for virus entry; $(b)$ the V3 hypervariable loop; $(c)$ the CD4 binding domain; and $(d)$ a region which spans the carboxy terminus of gp120 and the amino terminus of gp41. As indicated previously, studies have suggested a correlation between binding of maternal serum samples to regions of the $\mathrm{V} 3$ loop and protection of the fetus from infection (13-15). We examined binding of maternal serum samples to four different peptides from the V 3 region. We could not confirm an association between binding to V3 and protection from vertical transmission. One potential reason for this discrepancy was the use of different V3 peptides in the present study compared with those where an association was found. However, other investigators have also been unable to confirm the association of nontransmission and high-titered responses to $\mathrm{V} 3(26,27)$.

The gp4 1 transmembrane glycoprotein represents a logical candidate for the generation of neutralizing antibodies since it is involved in the fusion step between HIV and the target cell, and it cannot be shed from the surface of virally infected cells. In fact, there are several domains in the gp41 that have been shown to elicit neutralizing antibodies $(28-30)$. This is the first report, however, in which binding of maternal $\mathrm{HIV}^{+}$sera to a number of peptides spanning the gp4 1 glycoprotein has been examined.

Cell-free neutralization assays have been a useful in vitro method for the analysis of the anti-HIV potential of hyperimmune animal sera or $\mathrm{HIV}^{+}$sera. In several studies, neutralizing antibodies have been correlated with lesser manifestations and better clinical outcome. In addition, some have shown that decreasing neutralizing antibody titers indicate a poor prognosis $(31,32)$. However, other investigations have failed to demonstrate a clear correlation between neutralizing antibody activity and clinical state, prognosis, or vertical transmission status $(14,33-36) .9$ of 13 nontransmitting mothers exhibited significant neutralizing activity. In contrast, one of seven transmitting mothers exhibited significant neutralizing activity. If we assume no unusual bias in the sample population, this observation has direct importance for understanding the role of anti- 
HIV envelope humoral immune responses in preventing vertical transmission. As indicated, several studies have suggested an inverse correlation with reactivity to the $V 3$ region and vertical transmission. Recent other studies and data presented in this paper do not support this earlier association. One possible explanation for the observation is that neutralizing epitopes other than V3 epitopes could be involved, or that conformational epitopes (which may or may not involve anti-V3 responses) may collectively mediate protection from vertical transmission. The observation of neutralizing activity in one transmitting mother does not necessarily diminish the importance of this observation. Minor trauma or cell spread with or without trauma across the placenta may account for such transmission in the presence of neutralizing levels of antibodies. In any case, it will be important to determine with certainty which types of antibodies are responsible for the observed neutralization activity in these mothers.

There appears to be no correlation between antisyncytial activity of the maternal serum samples examined in this study and vertical transmission of HIV-1 infection. These data suggest that antisyncytial assays are not a useful means for identifying mothers who do not transmit HIV-1 infection to offspring.

Statistical analysis of the binding data indicates an association between reactivity with peptide 649 and nontransmission status. Experimental corroboration of this observation is ongoing. In addition, there appears to be a quantitative (number of peptides bound) differences in binding to gp41 and gp120 between the transmission and nontransmission groups. On average, sera from the nontransmission group bound to $\sim 33 \%$ more peptides than the samples from the transmission group. Interestingly, $100 \%$ of the sera samples from the nontransmission group, but only $43 \%$ of the samples from the transmission group, bound to at least one of the gp4 1 peptides. In addition, sera from the nontransmission group bound to an average of 2.2-fold more gp41 peptides than the samples from the transmission group. These data suggest a role for maternal humoral immunity to gp41 in protection from vertical transmission of HIV-1.

This report represents the first detailed analysis of maternal humoral immune responses to the HIV-1 envelope glycoproteins outside of the V3 hypervariable loop of gp120. Further study of the epitopes implicated herein may allow prediction of maternal humoral immune responses that protect the fetus from vertical transmission.

\section{Acknowledgments}

We would like to thank R. Shaina and L. Ann for their helpful comments and Alan Pickard for fluorescence activated cell sorting analysis.

This work was supported by grants from the American Foundation for AIDS Research, the Council for Tobacco Research, and a National Institutes of Health (NIH) First award to D.B. Weiner; an NIH First award, grants from the Lupus Foundations of Philadelphia Pennsylvania and America, the American Foundation for Aging Research, and the Scleroderma Federation to W.V. Williams; grants from the American Foundation for AIDS Research and from NIH to T. Kieber-Emmond; grants from the Pennsylvania Lupus Foundation and the American Foundation of AIDS Research to K.E. Ugen; and grants from the University of Pennsylvania Research Foundation and the McCabe Fund to I. Frank. K. E. Ugen is an American Foundation for AIDS Research/Pediatric AIDS Foundation Scholar.

\section{References}

1. Barre-Sinoussi, F., J. C. Cherman, F. Rey, M. T. Nugeyre, S. Chameret, J. Gruest, C. Dauguet, C. Axler-Blin, F. Ve'zinet-Brun, C. Rouzioux, et al. 1983. Isolation of a T-lymphotropic retrovirus from a patient at risk for acquired immune deficiency syndrome (AIDS). Science (Wash. DC). 220:868-870.

2. Gallo, R. C., P. S. Sarin, F. P. Gelmann, M. Robert-Gurnoff, E. Richardson, V. S. Kalyanaraman, D. L. Mann, G. D. Sidhu, R. E. Stahl, S. Zolla-Pazner, et al. 1984. Isolation of human $\mathrm{T}$ cell leukemia virus in acquired immune deficiency syndrome (AIDS). Science (Wash. DC). 220:865-867.

3. Lane, H. C., and A. S. Fauci. 1985. Immunologic abnormalities in the acquired immunodeficiency syndrome. Annu. Rev. Immunol. 3:477-500.

4. Koff, W. C., and D. F. Hoth. 1988. Development and testing of AIDS vaccine. Science (Wash. DC). 241:426-432.

5. Barnes, D. 1986. Grim projection for AIDS epidemic. Science (Wash. DC). 232:1589-1590.

6. Sprecher, S., G. Soumenkoff, F. Puissant, and M. Degueldre. 1986. Vertical transmission of HIV in 15-week fetus. Lancet. 2:288-289.

7. Jovaisas, E., M. Koch, A., Schafer, M. Stauber, and D. Lowenthal. 1985. LAV/HTLV-III in 20-week fetus. (Letter.) Lancet. 2:1129.

8. Cowan, M. C., D. Chudwin, D. Hellmann, D. Wara, R. Chang and A Ammann. 1984. Maternal transmission of acquired immune deficiency syndrome. Pediatrics. 73:382-386.

9. Ziegler, J., D. Cooper, R. Johnson, and J. Gold. 1985. Postnatal transmission of AIDS-associated retrovirus from mother to infant. Lancet. I:896-897.

10. Pizzo, P., J. Eddy, and J. Faloon. 1988. Acquired immune deficiency syndrome in children: Current problems and therapeutic considerations. Am J Med. 85 (Suppl 2A):195-202.

11. Lewis, S., C. Reynolds-Kohler, H. Fox, and J. Nelson. 1990. HIV-1 in trophoblastic and villous Hofbauer cells, and haematological precursors in eightweek fetuses. Lancet. 335:565-568.

12. Broliden, P. A., V. Moschese, K. Ljunggren, J. Rosen, C. Fundaro, A. Plebani, M. Jondal, P. Rossi, and B. Wahren. 1989. Diagnostic implication of specific immunoglobulin $\mathrm{G}$ patterns of children born to HIV-infected mothers. AIDS (Phila.). 3:577-582.

13. Rossi, P., V. Moschese, P. A. Broliden, C. Fundaro, I. Quinti, A. Plebani, C. Giaquinto, P. Tovo, K. Ljunggren, J. Rosen, et al. 1989. Presence of maternal antibodies to human immunodeficiency virus-1 envelope glycoprotein gp120 epitopes correlates with the uninfected status of children born to seropositive mothers. Proc. Natl. Acad. Sci. USA. 86:8055-8058.

14. Goedert, J., H. Mendez, J. Drummond, M. Robert-Guroff, H. Minkoff, S. Holman, R. Stevens, A. Rubinstein, W. Blattner, A. Willoughby, and S. H. Landesman. 1989. Mother-to-infant transmission of human immunodeficiency virus type 1: association with prematurity or low anti-gp120. Lancet. 2:1351-1354.

15. Devash, Y., T. A. Calvelli, D. Wood, K. Reagan, and A. Rubinstein. 1990 Vertical transmission of human immunodeficiency virus is correlated with the absence of high-affinity/avidity maternal antibodies to the gp120 principal neutralizing domain. Proc. Natl. Acad. Sci. USA. 87:3445-3449.

16. Auger, I., P. Thomas, V. De Gruttola, D. Morse, D. Moore, R. Williams, B. Truman, and C. E. Lawrence. 1988. Incubation periods for pediatric AIDS patients. Nature (Lond.). 336:575-577.

17. Centers for Disease Control. 1989. Interpretation and use of the Western blot assay for serodiagnosis of human immunodeficiency virus type 1 infections. Morbidity Mortality Weekly Report. 38:S1-7.

18. Centers for Disease Control. 1988 Update:serological testing for antibody to human immunodeficiency virus. Morbidity Mortality Weekly Report. 36:833845.

19. Centers For Disease Control 1987 Classification system for human immunodeficiency virus (HIV) infection in children under 13 years of age. Morbidity Mortality Weekly Report. 36:225-236.

20. Romano, C., W. V. Williams, D. J. Fischberg, N. Cocero, D. B. Weiner, M. I. Greene, and P. B. Molinoff. 1989. Subtype selective immunoprecipitation of the $\beta 2$-adrenergic receptor. J. Neurochem. 53:362-369.

21. Engvall, E. 1980. Enzyme immunoassay: ELISA and EMIT. Methods Immunol. Immunochem. 70:419-439.

22. Pierce, S. K., and N. R. Klinman. 1976. Allogeneic carrier specific enhancement of hapten-specific secondary B cell responses. J. Exp. Med. 144:1254 1262.

23. Williams, W. V., H. R. Guy, D. H. Rubin, F. Robey, J. N. Myers, T. Kieber-Emmons, D. B. Weiner, and M. I. Greene. 1988. Sequence of the cell-attachment sites of reovirus type 3 and its anti-idiotypic/antireceptor antibody: Modeling of their three-dimensional structures. Proc. Natl. Acad. Sci. USA. 85:6488-6492.

24. Bolognesi, D. P. 1989. HIV antibodies and vaccine design. AIDS (Phila.). 3:S111-S118.

25. Ugen, K. E., B. Perussia, M. Kamoun, M. Merva, W. V. Williams, P. Nara, T. K. Kieber-Emmons, and D. B. Weiner. (1991) Inhibition of HIV-1 Cellular Infection by Immunologic Reagents. In Vaccines 91 . Modern Approaches to New Vaccines Including Prevention of AIDS. R. M. Chanock, H. S. 
Ginsberg, F. Brown, and R. A. Lerner, editors. Cold Spring Harbor Laboratory Press, Cold Spring Harbor, NY. 115-121.

26. Jean-Pierre, A., T. Mathews, R. Coombs, J. Lambert, D. Wara, Y. Devash, S. Burchett, and Y. Bryson. 1991. Antibody to V3 loop peptides does not predict vertical transmission of HIV. VII International Conference on AIDS. Abstract W. C. 3263., p. 361.

27. Parkeh, B., N. Shaffer, C. Pau, E. Abrams, P. Thomas, H. Pollack, M. Bamji, A. Kaul, G. Schochetman, M. Rogers, J. R. George and The NYC Perinatal HIV Transmission Collaborative Group. 1991. Lack of correlation between maternal antibodies to $\mathrm{V} 3$ loop peptides of gp 120 and perinatal HIV-1 transmission. AIDS (Phila.). 5:1179-1184.

28. Chanh, T. C., G. R. Dreesman, P. Kanda, G. P. Linette, J. T. Sparrow, D. D. Ho, and R. C. Kennedy. 1986. Induction of anti-HIV neutralizing antibodies by synthetic peptides. EMBO (Eur. Mol. Biol. Organ.) J. 5:3065-3071.

29. Dalgleish, A. G., T. C. Chanh, R. C. Kennedy, P. Kanda, P. R. Clapham, and R. A. Weiss. 1988. Neutralization of diverse HIV-1 strains by monoclonal antibodies raised against a gp41 synthetic peptide. Virology. 165:209-215.

30. Thomas, E. K., J. N. Weber, J. McClure, P. R. Clapham, M. C. Singhal, M. K. Shriver, and R. A. Weiss. 1988. Neutralizing monoclonal antibodies to the AIDS virus. AIDS (Phila.). 2:25-29.

31. Weber, J. N. P. R Claphma R. A. Weiss, D. Parker, C. Roberts, J. Duncan, I. Weller, C. Carne, R. S. Tedder, A. J. Pinching, and R. Cheingsong-Popov. 1987. Human immunodeficiency virus infection in two cohorts of homosex- ual men: neutralising sera and association of anti-gag antibody with prognosis. Lancet. 1:119-121.

32. Sawyer, L. A., D. A. Katzenstein, R. M. Hendry, E. J. Boone, L. K. Vujcic, C. C. Williams, S. L. Zeger, A. J. Saah, C. R. Rinaldo, Jr., J. P. Phair, et al. 1990. Possible beneficial effects of neutralizing antibodies and antibody-dependent, cell-mediated cytotoxicity in human immunodeficiency virus infection. AIDS Res. Hum. Retroviruses. 6:341-356.

33. Vujcic, L. K., D. H. Shepp, M. Klutch, M. A. Wells, R. M. Hendry, A. E. Wittek, L. Krilov, and G. V. Quinnan, Jr. 1988. Use of a sensitive neutralization assay to measure the prevalence of antibodies to the human immunodeficiency virus. J. Infect. Dis. 157:1047-1050.

34. Wendler, I., U. Bienzle, and G. Hunsmann. 1987. Neutralizing antibodies and the course of HIV-induced disease. AIDS Res. Hum. Retroviruses. 3:157163.

35. Faulkner-Valle, G. P., A. DeRossi, O. Dalla Gassa, and L. Chieco-Bianchi. 1986. LAV/HTLV-III neutralizing antibodies in the sera of patients with AIDS, lymphadenopathy syndrome and asymptomatic seropositive individuals. Tumori. 72:219-224.

36. Ljunggren, K., V. Moschese, and P. Broliden 1990. Antibodies mediating cellular cytotoxicity and neutralization correlate with a better clinical stage in children born to human immunodeficiency virus infected mothers. J. Infect. Dis. 161:198-202. 